\title{
A case report: spontaneous postpartum rupture of unscarred uterus
}

\author{
Swati Singh $^{1 *}$, Ravinder Ahlawat ${ }^{2}$ \\ ${ }^{1}$ Department of Obstetrics and Gynecology, Civil Hospital, Gurugram, Haryana, India \\ ${ }^{2}$ Department of Health, DGHS, Panchkula, Haryana, India
}

Received: 08 June 2018

Accepted: 03 July 2018

\section{*Correspondence:}

Dr. Swati Singh,

E-mail: swati0019singh@gmail.com

Copyright: ( ) the author(s), publisher and licensee Medip Academy. This is an open-access article distributed under the terms of the Creative Commons Attribution Non-Commercial License, which permits unrestricted non-commercial use, distribution, and reproduction in any medium, provided the original work is properly cited.

\begin{abstract}
Rupture of uterus is characterized by a breach in the wall of the uterus involving its full thickness. An unscarred uterus rupture is uncommon. It has non-specific symptoms and presentation differs according to site and time of rupture. Authors report an unusual case of spontaneous rupture of unscarred uterus. A 32-year-old, pregnant woman, developed postpartum bleeding with no history of prior uterine incision. She was diagnosed as a case of rupture of uterus and emergency laparotomy was done. Early diagnosis and immediate surgical intervention may significantly improve the prognosis. Differential diagnosis of uterine rupture should always be kept in mind in all patients with or without risk factors.
\end{abstract}

Keywords: Postpartum bleeding, Uterine rupture, Vaginal birth

\section{INTRODUCTION}

Rupture of uterus is a rare obstetrical life-threatening complication. It is characterized by a breach in the uterine wall involving its full thickness, including the serosa. ${ }^{1,2}$ It can be associated with perinatal and maternal morbidity or mortality. ${ }^{3}$ A systematic review conducted by WHO including studies from urban and rural settings reported an overall incidence of uterine rupture in pregnant women as 1 in 2000 in community-based studies and 1 in 300 in facility-based studies. ${ }^{1}$ The incidence is markedly lower in the developed world.

The rupture of uterus can occur in both, scarred and unscarred uterus. The term scarred uterus is referred to the uterus of a woman that has previously undergone operation, most commonly cesarean section, which constitutes the main cause of overall uterine ruptures. ${ }^{4,5}$ The incidence of spontaneous rupture of unscarred uterus is 1 in 15,000 approximately. ${ }^{6}$ Authors report an unusual case of spontaneous rupture of an unscarred uterus in a 32-year-old woman, after uneventful vaginal delivery.

\section{CASE REPORT}

A 32-year-old, pregnant woman, Gravid 3, Para 2, Live 1 presented to present hospital with labour pains at 38 weeks gestation. Her obstetric history revealed two uncomplicated term vaginal deliveries. She had no history of any curettage or abdominal surgery. She was an unbooked case. The labor was uneventfully completed vaginally. A male baby was born with $3.4 \mathrm{~kg}$ birth weight and normal APGAR. The placenta was delivered spontaneously and was intact. The blood loss at the time of delivery was about $500 \mathrm{ml}$ and active management of third stage of labour was done.

Immediately after delivery, she developed postpartum bleeding with approximately $1000 \mathrm{ml}$ blood loss. On examination, the fundus of uterus was above the level of umbilicus and uterus was not contracted. Therefore, management of postpartum bleeding was done by intravenous infusion of oxytocics and misoprostol. The blood clots were removed from the uterus manually. The uterus contracted satisfactorily. However, vaginal bleeding continued despite of medical treatment. On per 
speculum examination, no tear was present. On bimanual examination, rent was felt at left posterolateral surface of uterus. Rupture of uterus was suspected, and immediate ultrasound was done. On ultrasound, outline of uterus was seemed to be disrupted and free fluid in pelvis was seen.

Accordingly, it was decided to perform laparotomy and proceed. Intraoperative exploration revealed a rupture area on the left posterolateral wall with left uterine artery involvement and extension of rupture in left parametrium. Therefore, decision of hysterectomy was made intraoperatively, as conservative surgical management was not possible. Hysterectomy with left salpingooophrectomy was done. Right side ovary was preserved. Patient received two units blood and 2 units of packed cells during intraoperative and postoperative period. The postoperative period was uneventful, and patient was discharged on eight postoperative day after stitch removal.

\section{DISCUSSION}

Uterine rupture is a rare but serious obstetric complication. The overall incidence of uterine rupture is $0.05 \%$ of total deliveries. ${ }^{7}$

The incidence of rupture of uterus also depends on level of medical care and presence of previous surgeries on uterus. Approximately $90 \%$ of these cases occur in women with a uterine scar, most commonly from a previous caesarean section. The incidence of spontaneous rupture in a previously intact uterus is approximately 1 in $15,000 .^{6}$

Advanced maternal age, grand multiparity, macrosomia, multiple gestation, prolonged labor, uterine anomalies, abnormal plantation, trauma, obstetric maneuvers (e.g. internal version and breech extraction, instrumental delivery), labour induction and augmentation are the other risk factors for uterine rupture. ${ }^{8}$ Multiparity was the only possible risk factor in this patient.

The signs and symptoms of uterine rupture are nonspecific and depends on site of rupture. Clinical signs and symptoms are fetal bradycardia, abdominal pain vaginal bleeding, maternal tachycardia and hypotension. ${ }^{9}$ However, these signs are not always present, and the presentation is often non-specific. In present patient, vaginal bleeding was the only symptom.

Common sites of rupture include the posterior uterine wall, the anterior wall, the lateral aspect of the uterus, the fundus and the lower uterine segment. ${ }^{7}$ In present case, site of rupture was left posterolateral wall with left uterine artery involvement and extension up to left parametrium. After the diagnosis of rupture of uterus, next step is aggressive replacement of fluids with crystalloids and blood and blood products, along with simultaneous preparation for emergency laparotomy and proceed. ${ }^{10}$

Early diagnosis and proceeding with surgical intervention can significantly affect the prognosis.

\section{CONCLUSION}

Uterine rupture is a rare but serious obstetrical complication. It is difficult to diagnose because of its vague signs and symptoms. Although, rupture of uterus in the developed world is typically associated with previous caesarean section or other uterine instrumentation, it can occur in a previously unscarred uterus and should remain in the differential diagnosis of postpartum haemorrhage.

Funding: No funding sources

Conflict of interest: None declared

Ethical approval: Not required

\section{REFERENCES}

1. Hofmeyr GJ, Gulmezoglu MM. WHO systematic review of maternal mortality and morbidity: the prevalence of uterine rupture. BJOG. 2005;112:1221-8.

2. Mavromatidis G, Karavas G, Margioula-Siarkou C, Pertousis S. Spontaneous postpartum rupture of an intact uterus: a case report. J Med Clin Res. 2015;7(1):56-8.

3. Turner MJ. Uterine Rupture. Best Pract Res Clin Obstet Gynaecol. 2002;16:69-79.

4. Ronel D, Wiznitzer A, Sergienko R, Zlotnik A, Sheiner E. Trends, risk factors and pregnancy outcome in women with uterine rupture. Arch Gynecol Obstet. 2012;285(2):317-21.

5. Wang PH, Yuan CC, Chao HT, Yang MJ, Ng HT. Posterior uterine wall rupture during labour. Hum Reprod. 2000;15(5):1198-9.

6. Siddiqui M, Ranasinghe JS. Spontaneous rupture of uterus. J Clin Anesth. 2002;14(5):368-70.

7. Ripley DL. Uterine emergencies. Obstet Gynecol Clin North Am. 1999;26(3):419-34.

8. Zwart JJ, Richters JM, Ory F, deVrics JI, Bleomenkump $\mathrm{KW}$, van Rousmalen J. Uterine rupture in the Netherlands: a nationwide population-based cohort study. BJOG. 2009;116:1069-80.

9. Mazzone ME, Woolever J. Uterine rupture in a patient with an unscarred uterus: a case study. WMJ. 2006;105:64-6.

10. Dare B, Dove C. Maternal death after uterine rupture in an unscarred uterus: a case report. J Emerg Med. 2009;37(4):393-5.

Cite this article as: Singh $\mathrm{S}$, Ahlawat R. A case report: spontaneous postpartum rupture of unscarred uterus. Int J Reprod Contracept Obstet Gynecol 2018;7:3420-1. 